\title{
Evaluation of The Association Between Mandibular Canal and Mandibular Third Molars On Cone Beam Computerized Tomography (CBCT)
}

\author{
Gaye Keser(0000-0001-7564-4757) ${ }^{\alpha}$, Emre Ergun(0000-0002-3368-845X) ${ }^{\beta}$, Filiz Namdar Pekiner(0000-0001-7426-5587) ${ }^{\alpha}$
}

Selcuk Dent J, 2021; 8: 1-7 (Doi: 10.15311/selcukdentj.776842)

Bașuru Tarihi: 04 Ağustos 2020 Yayına Kabul Tarihi: 02 Ocak 2021

\section{ABSTRACT}

Evaluation of The Association Between Mandibular Canal And Mandibular Third Molars On Cone Beam Computerized Tomography (CBCT)

Background: The aim of this study was to assess the relationship between an impacted third molar and mandibular canal on cone beam CT (CBCT) images using a radiological classification.

Methods: The relationship between the third molar teeth and the mandibular canal, the distance of the third molar to the inferior alveolar canal, buccal-apical-lingual position of the canal relative to the tooth, and the presence of contact between the canal and the third molar teeth were evaluated according to the classification. According to these criteria, a total of eight classifications and two subtypes, class $A$ and $B$, were made. $\mathrm{CBCT}$ images of 50 patients were independently studied all the possible relationships between third molar and IAN (Inferior Alveolar Nerve) on the cross-sectional images. IBM SPSS 22.0 was used for the statistical analysis.

Results: For the lower left third molar teeth (38), it was found that the most common class was $1 \mathrm{~A}(48,6 \%)$ in gender-free examination. For the third molar teeth (48) in the lower right mandibula, the most common class was $1 \mathrm{~A}(45 \%)$ regardless of the gender.

Conclusion: The use of this classification could be a valid support in clinical practice to obtain a common language among clinicians in order to define the possible relationships between an impacted third molar and the mandibular canal on CBCT images.

\section{KEYWORDS}

Cone Beam computed tomography, third molar, mandibular canal

The mandibular canal is an intramedullary tubular structure. It begins from the the mandibular foramen and comes out from mental foramen near the lingual surface of the mandible. The vessel-nerve bundle that passes through the mandibular canal is called inferior alveolar nerve. The location of the mandibular canal is also very important because of the surgical procedures performed. ${ }^{1,2}$

The position of the mandibular canal is extremely during mandibular third molar tooth extraction, which

\section{öz}

Üçüncü Molar Dişlerin Mandibular Kanal ile Iliş̧isinin Konik Işınlı Bilgisayarlı Tomografi (KIBT) ile Değerlendirilmesi

Amaç: Bu çalışmanın amacı, Konik Işınlı Bilgisayarlı Tomografi (KIBT) görüntülerinde gömük üçüncü molar ve mandibular kanal arasındaki ilişkinin radyolojik bir sınılama kullanılarak değerlendirilmesidir.

Gereç ve Yöntemler: Çalışmada üçüncü molar dişlerin mandibular kanal ile olan ilişkileri, üçüncü molar dişin inferior alveolar kanala olan uzaklığı, kanalın dişe göre bukkal-apikal-lingual pozisyonu, kanal ile üçüncü molar dişlerin arasında temas olup olmaması gibi kriterler göz önünde bulundurularak yapılan sınıflamaya göre değerlendirilmiştir. Bu kriterlere göre 0 (sıfır) ile 7 arasında toplam sekiz adet ve "A ve B" olmak üzere iki adet alt grup ile sınılandırma yapılmıştır. 50 hastanın KIBT görüntüleri kesitsel görüntülerde üçüncü molar ile madibular kanal arasındaki muhtemel tüm ilişkiler bağımsız bir şekilde incelenmiştir. Daha sonra, çalışma populasyonu bu sınıflamaya göre alt bölümlere ayrılmıştır. İstatistiksel analiz için IBM SPSS 22.0 programı kullanılmıştır.

Bulgular: Alt sol üçüncü molar dişlerde (38) cinsiyete dayalı değerlendirmede en sık görülen sınıfın $1 \mathrm{~A}(\%$ 48,6) olduğu bulgulanmıştır. Her iki cinsiyette en sık görülen $1 \mathrm{~A}$ sınıfı kadınlarda \% 23 ve erkeklerde \% 23,4 olmuştur. Sağ alttaki üçüncü molar dişler için (48), en yaygın sınıfın cinsiyete bakılmaksızın 1A (\% 45) olduğu tespit edilmiştir.

Sonuç: Bu sınıflamanın kullanımı, KIBT görüntülerinde üçüncü molar ve mandibular kanal arasındaki olası ilişkileri tanımlamada klinisyenler arasında ortak bir dil elde etmek için klinik uygulamada geçerli bir yöntem olmaktadır.

\section{ANAHTAR KELIMELER}

Konik ışınlı bilgisayarlı tomografi, üçüncü molar, mandibular kanal

is one of the most frequently performed dentoalveolar surgical procedures in the lower canal. ${ }^{2,3}$ Inferior alveolar nerve paralysis is the major complication during this procedure. $^{3}$ As a result, temporary or permanent nerve damage may occur. Nerve damage can result in paresthesia, dysesthesia, and hypoesthesia of the lower lip, lower teeth, gingiva, and jaw skin. ${ }^{1-4}$

According to the studies performed, the incidence of temporary injury of inferior alveolar nerve after extracting mandibular third molar teeth is between $1 \%$ and $7 \%$.

\footnotetext{
${ }^{\alpha}$ Marmara University Faculty of Dentistry, Department of Oral Diagnosis and Maxillofacial Radiology, İstanbul

$\beta$ Karadeniz Technical University, Department of Periodontology, Trabzon
} 
Permanent damage is less frequent and is between 0.01 and $2 \% .^{3-5}$ The incidence of these complications may increase with radiographic changes in the root and canal. These changes determined by Rood and Shehab, are thinning, bending, and darkening and superimposing of the roots with the mandibular canal in the two-dimensional radiographs and the interruption and narrowing of the white line of the mandibular canal. ${ }^{6}$ The darkening of the root is defined as the radiolucent image portrayed on radiographic film when third molar tooth root is superimposed on the mandibular canal. This image may also be due to the thinness of the lingual cortical bone only and may not be related with any root. In a study where 18 patients with panoramic examinations that reveal no darkening of the root and no detachment of the radiopaque line of the mandibular canal, their cone beam computed tomography (CBCT) images revealed that $50 \%$ of the third molar teeth were in contact with mandibular canal. ${ }^{7}$

CBCT is one of the most important modalities in dental radiology. ${ }^{8}$ The first model scanner for CBCT was defined in 1982 for angiographic applications and for dentomaxillofacial use a CBCT scanner was described in the late 1990s. ${ }^{9,10}$ An X-ray source and detector are fixed in a rotating gantry where the imaging process is accomplished. All three dimensions of the image voxels are the same in CBCT and volumetric data is isotropic. This makes it possible to reorient the images to fit the patient's anatomic features and perform realtime measurements. It can generate a size of voxel (a 3D cuboid unit of images) as small as submilimeter in dimension, which leads to its high resolution and quality. CBCT units provide choices for field of view (FOV), which allows irradiation of particular area of interest to dentists, while limiting irradiation of other tissues. The radiation dose from a CBCT is lower than that from a conventional $\mathrm{CT}$, but is significantly higher than traditional dental radiography techniques. ${ }^{10-12}$

The aim of this study was to assess the relationship between an impacted third molar and mandibular canal on CBCT images using a radiological classification.

\section{MATERIALS AND METHODS}

The study protocol of this study was approved by Marmara University School of Medicine NonInterventional Clinical Research Ethics Committee on 24.07.202 with protocol number 09.2020.931. This study was carried out on a total of 50 patients, aged between 22 and 63 years, with a mean age of $39.02 \pm$ 8.57, 37 females and 13 males, in the CBCT archive of the Marmara University Dentistry and Oral and Maxillofacial Radiology Department. Patients with no third molar or currently developing third molar teeth, were not included in the study group. CBCT records of were not included in the study group. CBCT records of all patients were created with Planmeca Promax 3D Mid (Planmeca Oy, Helsinki, Finland, 2012) brand device. The operating parameters of the device are reported by the manufacturer as $90 \mathrm{kV}, 10 \mathrm{~mA}$ and 36 sec.

To ensure a professional and efficient evaluation, during meetings for the pilot study, the fifth grade student (E.E.) was trained to evaluate tomographic images by specialist (F.N.P.) who had been working in Oral Diagnosis and Radiology for fifteen years or more, and an agreement on the objective criteria for the qualitative evaluation of the images was determined. One dentist (FNP) and 5th grade graduation thesis student (EE) participated in the survey and calibration trials were performed initially to ensure an inter-examiner consistency of at least $85 \%$ in recording. For calibration, 20 patients were evaluated and not included in the main study. Interexaminer agreement was measured by Cohen's Kappa statististic.

In this study, we evaluated the relation between the third molar teeth with the mandibular canal, the distance from the third molar tooth to the inferior alveolar nerve, the buccal-apical-lingual position of the canal with respect to the tooth, and the contact between the canal and third molar teeth. Maglione et al. ${ }^{13}$ introduced a radiological classification that could be normally used in clinical practice to assess the relationship between an impacted third molar and mandibular canal on CBCT images. According to this classification:

- Class 1: the mandibular canal runs apically or buccally with respect to the tooth but without touching it (the cortical limitations of the canal are not interrupted).

Subtype 1A: the distance Inferior Alveolar Nerve (IAN)/tooth is greater than $2 \mathrm{~mm}$ (Figure 1);

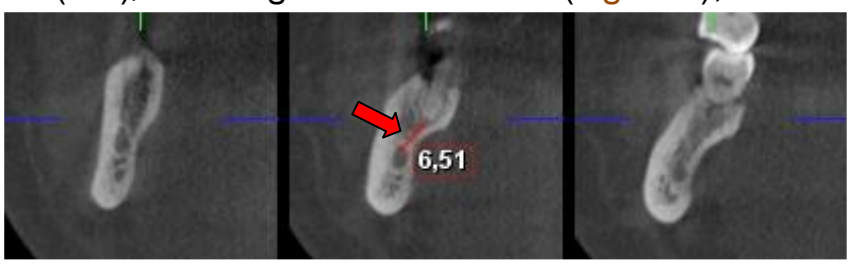

Figure 1

Cross-section plane: Tooth number 38 is classified as $1 \mathrm{~A}$ ( shown with a red arrow). The mandibular canal runs apically with respect to the tooth but without touching it and the distance Inferior Alveolar Nerve (IAN)/tooth is greater than $2 \mathrm{~mm}$. 
subtype 1B: the distance IAN/tooth is less than 2 $\mathrm{mm}$ (Figure 2);

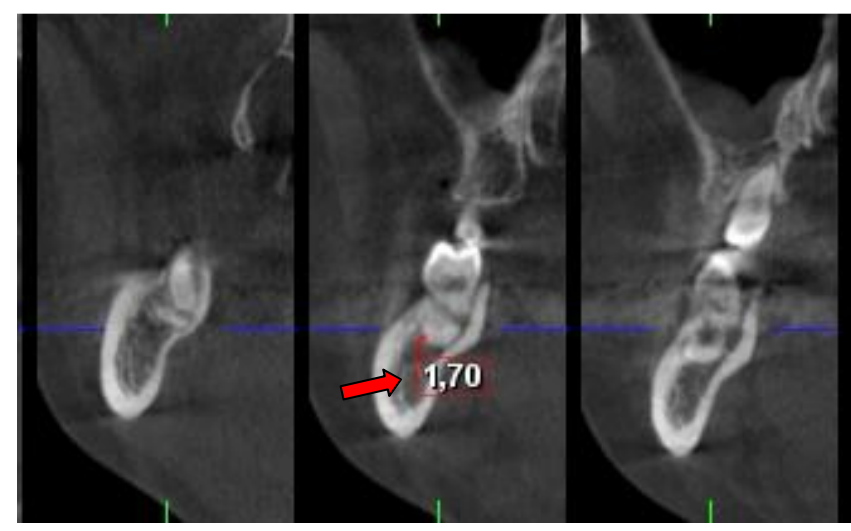

Figure 2

Cross-section plane: Tooth number 48 is classified as $1 \mathrm{~B}$ ( shown with a red arrow). The mandibular canal runs apically with respect to the tooth but without touching it and the distance Inferior Alveolar Nerve (IAN)/tooth is less than $2 \mathrm{~mm}$.

- Class 2: the mandibular canal runs lingually to the tooth without touching it (the cortical limitations of the canal are not interrupted).

Subtype 2A: the distance IAN/tooth is longer than $2 \mathrm{~mm}$; subtype $2 \mathrm{~B}$ : the distance IAN/tooth is less than $2 \mathrm{~mm}$;

- Class 3: the mandibular canal runs apical or buccal touching the tooth.

- Subtype 3A: in the point of contact the mandibular canal shows a preserved diameter;

Subtype 3B: in the point of contact the mandibular canal shows a smaller calibre and/or an interruption of the corticalization (Figure 3);

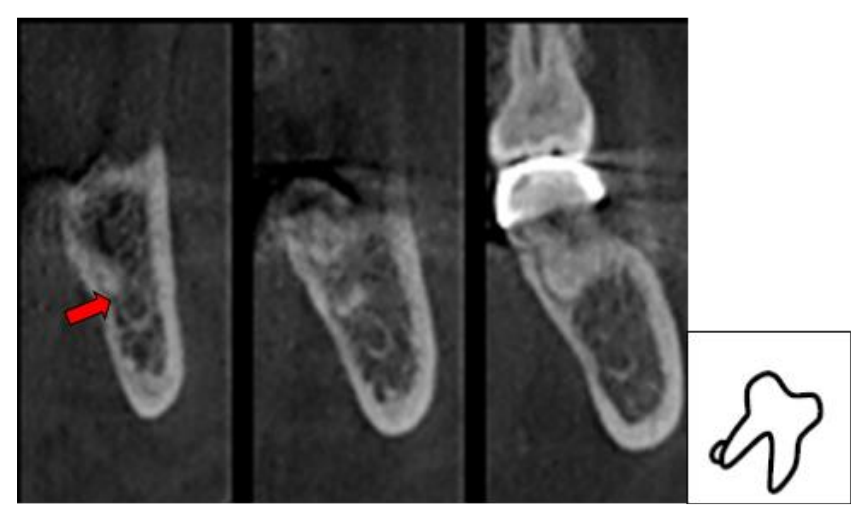

Figure 3

Cross-section plane and scheme of the relationshipbetween tooth/IAN: Tooth number 38 is classified as 3B (shown with a red arrow). The mandibular canal runs apical or buccal touching the tooth and in the point of contact the mandibular canal shows an interruption of the corticalization.
- Class 4: the mandibular canal runs lingually touching the tooth.

Subtype 4A: in the point of contact the mandibular canal shows a preserved diameter;

Subtype 4B: in the point of contact the mandibular canal shows a smaller calibre and/or an interruption of the corticalization (Figure 4);

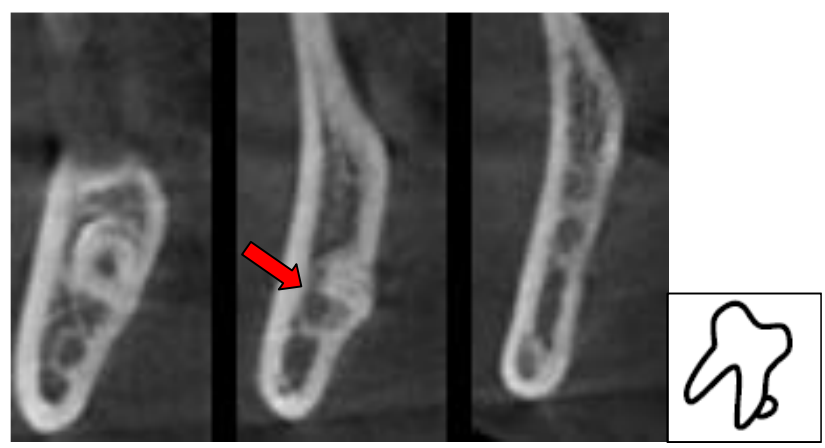

Figure 4

Cross-section plane and scheme of the relationshipbetween tooth/IAN: Tooth number 48 is classified as $4 \mathrm{~B}$ (shown with a red arrow). The mandibular canal runs lingually touching the tooth and in the point of contact the mandibular canal shows an interruption of the corticalization.

- Class 5: the mandibular canal runs between the roots but without touching them.

Subtype $5 \mathrm{~A}$ : the distance IAN/tooth is greater than $2 \mathrm{~mm}$; subtype $5 \mathrm{~B}$ : the distance IAN/tooth is less than $2 \mathrm{~mm}$;

- Class 6: the mandibular canal runs between the roots touching them.

Subtype 6A: in the point of contact the mandibular canal shows a preserved diameter; subtype 6B: in the point of contact the mandibular canal shows a smaller calibre and/or an interruption of the corticalization;

- Class 7: the mandibular canal runs between fused roots.

The existence of molar tooth and IAN relationship was investigated on coronal and cross-sectional planes with $0.40 \mathrm{~mm}$ slice thickness in bilateral molar and angle-ramus regions .

IBM SPSS Statistics 22.0 (IBM SPSS, Turkey) program is used for statistical analysis. Descriptive statistical methods (frequency) as well as qualitative data were compared using the Chi-Square test and Fisher's Exact test. Significance was assessed at $p<0.05$ level.

\section{RESULTS}

Of the 50 patients examined, 13 were male (26\%) and 37 were female $(74 \%)$. The left mandibular third molar teeth of the patients were identified as 38 and the right third molar teeth as 48 . The classification was made for the teeth numbered 38 and for the 48 separately. We did not find a tooth belonging to classifications $0,2 \mathrm{~B}, 4 \mathrm{~A}, 5 \mathrm{~A}, 5 \mathrm{~B}, 6 \mathrm{~A}, 6 \mathrm{~B}, 7$ for both 
left and right third molar teeth in our male and female patients (Table 1).

Table 1.

\section{Gender distribution of CBCT radiographic classifications for left lower third molar teeth (38)}

\begin{tabular}{|c|c|c|c|}
\hline $\begin{array}{c}\text { CBCT } \\
\text { Radiographic } \\
\text { classification } \\
\text { (tooth number } 38 \text { ) }\end{array}$ & $\begin{array}{l}\text { Female } \\
\mathrm{n}(\%)\end{array}$ & $\begin{array}{l}\text { Male } \\
\text { n (\%) }\end{array}$ & $\begin{array}{l}\text { Total } \\
\text { n (\%) }\end{array}$ \\
\hline 0 & $0(\% 0)$ & $0(\% 0)$ & $0(\% 0)$ \\
\hline $1 \mathrm{~A}$ & $10(\% 20)$ & $9(\% 18)$ & $19(\% 38)$ \\
\hline 1B & $8(\% 16)$ & $1(\% 2)$ & $9(\% 18)$ \\
\hline $2 \mathrm{~A}$ & $0(\% 0)$ & $3(\% 6)$ & $3(\% 6)$ \\
\hline $2 B$ & $0(\% 0)$ & $0(\% 0)$ & $0(\% 0)$ \\
\hline $3 \mathrm{~A}$ & $9(\% 18)$ & $0(\% 0)$ & $9(\% 18)$ \\
\hline 3B & $5(\% 10)$ & $0(\% 0)$ & $5(\% 10)$ \\
\hline $4 \mathrm{~A}$ & $0(\% 0)$ & $0(\% 0)$ & $0(\% 0)$ \\
\hline 4B & $5(\% 10)$ & $0(\% 0)$ & $5(\% 10)$ \\
\hline $5 \mathrm{~A}$ & $0(\% 0)$ & $0(\% 0)$ & $0(\% 0)$ \\
\hline $5 B$ & $0(\% 0)$ & $0(\% 0)$ & $0(\% 0)$ \\
\hline $6 \mathrm{~A}$ & $0(\% 0)$ & $0(\% 0)$ & $0(\% 0)$ \\
\hline $6 \mathrm{~B}$ & $0(\% 0)$ & $0(\% 0)$ & $0(\% 0)$ \\
\hline 7 & $0(\% 0)$ & $0(\% 0)$ & $0(\% 0)$ \\
\hline
\end{tabular}

The most common grade for tooth number 38 is $1 \mathrm{~A}$ for both genders. Classes $3 \mathrm{~A}, 3 \mathrm{~B}$ and $4 \mathrm{~B}$ seen in female patients but not in male patients. For both genders, the most common class for teeth number 48 is $1 \mathrm{~A}$. Class $2 \mathrm{~A}$ is seen among male patients but not in female patients. Class 4B was seen in our female patients but not in male patients. There was no significant relationship between gender and radiographic classification for right and left third molar teeth $(p>0.05)$ (Table 2).

Table 2.

Gender distribution of $\mathrm{CBCT}$ radiographic classifications for right lower third molar teeth (48)

\begin{tabular}{|llll|}
\hline $\begin{array}{c}\text { CBCT Radiographic } \\
\text { classification } \\
\text { (tooth number 48) }\end{array}$ & $\begin{array}{l}\text { Female } \\
\mathrm{n}(\%)\end{array}$ & $\begin{array}{l}\text { Male } \\
\mathrm{n}(\%)\end{array}$ & $\begin{array}{l}\text { Total } \\
\mathrm{n}(\%)\end{array}$ \\
\hline 0 & $0(\% 0)$ & $0(\% 0)$ & $0(\% 0)$ \\
\hline 1A & $14(\% 28)$ & $6(\% 12)$ & $20(\% 40)$ \\
\hline 1B & $7(\% 14)$ & $0(\% 0)$ & $7(\% 14)$ \\
\hline 2A & $0(\% 0)$ & $3(\% 6)$ & $3(\% 6)$ \\
\hline 2B & $0(\% 0)$ & $0(\% 0)$ & $0(\% 0)$ \\
\hline 3A & $2(\% 4)$ & $3(\% 6)$ & $5(\% 10)$ \\
\hline $4 \mathrm{~A}$ & $6(\% 12)$ & $1(\% 2)$ & $7(\% 14)$ \\
\hline $4 \mathrm{~B}$ & $0(\% 0)$ & $0(\% 0)$ & $0(\% 0)$ \\
\hline 5B & $8(\% 16)$ & $0(\% 0)$ & $8(\% 16)$ \\
\hline $6 \mathrm{~A}$ & $0(\% 0)$ & $0(\% 0)$ & $0(\% 0)$ \\
\hline $6 \mathrm{~B}$ & $0(\% 0)$ & $0(\% 0)$ & $0(\% 0)$ \\
\hline 7 & $0(\% 0)$ & $0(\% 0)$ & $0(\% 0)$ \\
\hline
\end{tabular}

The contact of mandibular canal with apical, buccal and lingual positioning of teeth number 38 and 48 were examined and it was found that there was a significant relationship between the position of the teeth and the contact with the mandibular canal for both mandibular third molars $(p<0.05)$ (Table 3$)$.
Table 3.

Gender distribution of CBCT radiographic classifications for left lower third molar teeth (38)

\begin{tabular}{|c|c|c|c|c|}
\hline \multirow[t]{4}{*}{$\begin{array}{l}\text { Tooth } \\
\text { number } 38\end{array}$} & & $\begin{array}{l}\text { Contact } \\
\text { n (\%) }\end{array}$ & $\begin{array}{l}\text { No contact } \\
\text { n (\%) }\end{array}$ & $p$ \\
\hline & \multirow[b]{2}{*}{$\begin{array}{l}\text { Buccal or } \\
\text { apical }\end{array}$} & $2(6,1 \%)$ & 31 (93,9\%) & \multirow{3}{*}{${ }^{1} 0.005$} \\
\hline & & & & \\
\hline & Lingual & $3(75,0 \%)$ & $1(25,0 \%)$ & \\
\hline \multicolumn{5}{|l|}{$\begin{array}{l}\text { Tooth } \\
\text { number } 48\end{array}$} \\
\hline & \multirow{3}{*}{$\begin{array}{l}\text { Buccal or } \\
\text { apical }\end{array}$} & $5(15,2 \%)$ & $28(84,8 \%)$ & \multirow{4}{*}{${ }^{2} 0.001$} \\
\hline & & & & \\
\hline & & 21 (42.9\%) & 17 (33.3\%) & \\
\hline & Lingual & & & \\
\hline
\end{tabular}

\section{DISCUSSION}

Inferior alveolar nerve damage is often encountered during surgical removal of mandibular third molar teeth. The reported incidence of nerve damage was between $0.4 \%$ and $8.4 \%$. Preoperatively, relative position must be well defined in order to protect from mechanical damage during surgery. Therefore, preoperative radiographic examination is routinely used in this process. $^{14}$

Radiographically, the third molar teeth are examined with two classifications according to position and inclusion. In Pell \& Gregory (P\&G) classification system third molar teeth are examined in 9 different groups according to their vertical and horizontal positions.1315 In the vertical category, cemento-enamel junction and occlusal plane are used as references. The horizontal plane is categorized by looking at its position relative to the ramus. In the Winter classification, evaluation is made according to the slopes of the longitudinal axis of the teeth. Teeth are categorized as mesio-angular, horizontal, vertical and distangular in this class. $^{15}$ Winter and P\&G classifications give information about the difficulty of surgical operation, but do not give information about the relationship of the mandibular canal with the third molar and possible nerve damage.

Panoramic radiography is one of the most commonly used methods to evaluate the preoperative risk of inferior alveolar nerve damage. Yet, the deterioration of the continuity of the cortical structure in the mandibular canal is not evident. In addition, it is impossible to determine the buccal-lingual position in two- 
dimensional radiograph. Darkening of the root canal of third molar teeth at the level of mandibular canal offers a possible relationship between them, and thus there could be a nerve damage after tooth extraction. However, in a study conducted, it is stated that, this radiographic image may be a proof that the lingual cortical bone may be thin or there may be a perforation. ${ }^{16}$

Szalma et al. ${ }^{17}$ examined the association between the darkening of the root on the preoperative panoramic radiograph and intraoperative IAN exposure and it was stated that the IAN was visible in $47(15.2 \%)$ of 309 intraoperative extractions. Moreover, darkening of the third molar roots was significantly associated with IAN exposure $(p<.001)$.

The gold standard technique used in the preoperative estimation of inferior alveolar nerve damage according to a study conducted is CBCT. ${ }^{18}$ According to another study, CBCT was found to be a more reliable technique for determining the number of roots compared to panoramic radiography. ${ }^{19}$ Lee et al. ${ }^{20}$ stated in their study that three-dimensional radiographic examination of the third molar teeth prior to surgical excision is necessary to determine the position and proximity to the inferior alveolar nerve for preventing nerve damage.

CBCT provides a more advanced projection than panoramic radiography and gives images that are more accurate with buccal and lingual positions on coronal sections. ${ }^{21}$ According to a study, inferior alveolar nerve damage was found more frequently on the lingual side of the canal. ${ }^{22} \mathrm{Kim}$ et al. ${ }^{23}$ reported that in 51 cases $(71.8 \%)$ mandibular canal was found in lingual position and and roots and inferior alveolar nerve were found in contact with each other in their study. Moreover our research revealed that contact with inferior alveolar nerve was detected in lingual positon in $75 \%$ teeth number 38. Care should be given during the third molar tooth surgery because the nerve damage is higher in canals with lingual position. After the preoperative radiographic evaluation, the nerve damage is prevented by moving the root in lingual direction which is the opposite direction of the mandibular canal. ${ }^{7}$ The surgeon may cause nerve damage if bucco-lingual position was missed due to the forces coming from the lingual side of the canal. ${ }^{24}$

One of the parameters we included in our study was the distance between the canal and the third molar tooth. Sammartino et al. ${ }^{25}$ suggested in their study that $1.5 \mathrm{~mm}$ safe distance between the mandibular canal and the implant is neccessary to protect against indirect damage of mandibular canal. For this reason, the critera in our study was based on $2 \mathrm{~mm} .{ }^{11}$

Jhamp et al. ${ }^{21}$ examined the relationship between the mandibular canal and the third molar in four different categories. It is reported that nerve damage was found in the distorted cortical structure. According to another study, the risk of inferior alveolar damage after paralysis of the third molar tooth was increased in destructed cortical. ${ }^{26}$

In our study, 13 male, (\%26) and 37 female (\%74), a total of 50 patients were evaluated. The left third (38) and right (48) lower third molar teeth were studied separately in both genders. In 37 of 50 patients, the left lower third molar tooth (38) could be evaluated. For the lower left third molar teeth (38), it was found to be that the most common class was $1 \mathrm{~A}(38 \%)$ in gender-free examination. Female (20\%) and male (18\%) were the most common class of $1 \mathrm{~A}$ for both genders. $2 \mathrm{~A}, 2 \mathrm{~B}, 4 \mathrm{~A}$, $5 A, 5 B, 6 A, 6 B, 7$ classes were not found in both genders. Classes $3 \mathrm{~A}, 3 \mathrm{~B}$ and $4 \mathrm{~B}$ were the ones that were found in females but not in males. The right third molar (48) could be examined in 40 of 50 patients. For the third molar teeth (48) in the lower right, it was found to be that the most common class was $1 \mathrm{~A}(40 \%)$ regardless of the gender. For female patients, $1 \mathrm{~A}(28 \%)$ was the most frequent and the second most frequent was class 4B (16\%). Moreover, for male patients $1 \mathrm{~A}$ class $(12 \%)$ was the most frequent class. The only class that was found in males but not in females was class $2 \mathrm{~A}$. Classes $1 \mathrm{~B}$ and $4 \mathrm{~B}$ were found in female patients but not in male patients.

This classification used in our study has made it easier to explain these cases by providing a common language to surgeons and radiologists. In addition, this classification has been used to predict and possibly prevent paresthesia that may occur in nerve end-stage patients who may be preoperatively inferior alveolar canal.

\section{CONCLUSION}

According to the examinations, it is more likely that teeth are in contact with IAN in cases where vascular nerve pack is located lingually from the tooth. This increases the risk of damage to the nerve during third molar surgery. Preoperative radiographic evaluation provides the possibility of informing the clinician more clearly about the difficulty of surgical operation and possible nerve damage with the resultant classification. 


\section{REFERENCES}

1. Castro MAA, Lagravere-Vich MO, Amaral TMP, Abreu MHG, Mesquita RA. Classification of mandibular canal branching: Areview of literature. World Journal of Radiology 2015:531-2.

2. Libersa $P$, Savignat M, Tonnel A. Neurosensory disturbances of the inferior alveolar nerve: retrospective study of complaints in a 10-year period. J Oral Maxillofac Surg 2007.;65(8):1486-89.

3. Peker I, Sarikir C, Alkurt MT, Zor ZF. Panoramic radiography and cone-beam computed tomography findings in preoperative examination of impacted mandibular third molars. BMC Oral Health 2014; $14 ; 14: 71$

4. Mukherjee S, Vikraman B, Sankar D, Veerabahu MS. Evaluation of Outcome Following Coronectomy for the Management of Mandibular Third Molars in Close Proximity to Inferior Alveolar Nerve. Journal of Clinical and Diagnostic Research 2016; 10(8):ZC57-62

5. Weckx A, Agbaje JO, Sun Y, Jacobs R, Politis C. Visualization techniques of the inferior alveolar nerve (IAN): a narrative review. Surg Radiol Anat 2016;38(1):55-63.

6. Rood JP, Shehab BAAN. The radiological prediction of inferior alveolar nerve injury during third molar surgery. British Journal of Oral \& Maxillofaical Surgery 1990;28(1):20-5.

7. Jung Y-H, Nah K-S, Cho B-H. Correlation of panoramic radiographs and cone beam computed tomography in the assessment of superimposed relationship between the mandibular canal and impacted third molars. Imaging Science in Dentistry 2012;42(3):121-7.

8. Aktan AM, Güngör E, Çiftçi ME. Diş Hekimliğinde Konik Işınlı Bilgisayarlı Tomografi Kullanımı. Atatürk Üniv Diş Hek Fak Derg 2015 ;25: 71-76.

9. Mayil M., Keser G., Pekiner FN. CBCT Images of anatomic landmarks in maxillofacial region. CEHS 2014;4:232-240.

10.Carter L, Farman AG, Geist J, Scarfe WC, Angelopoulos C, Nair MK, Hildebolt CF, Tyndall D, Shrout M. American Academy of Oral Maxillofacial Radiology executive opinion statement on performing and interpreting diagnostic cone beam computed tomography. Oral Surg Oral Med Oral Pathol Oral Radiol Endod. 2008;106:561-2.

11. Razavi T, Palmer RD, Davies J, Wilson R, Palmer PJ. Accuracy of measuring the cortical bone thickness adjacent to dental implants using cone beam computed tomography. Clin Oral Implants Res. 2010;23:718-725.

12.Adibi S, Zhang W, Servos T, O'Neill PN. Cone Beam Computed Tomography in Dentistry: What Dental Educators and Learners Should Know. J Dent Educ. 2009; 76:1437--42.

13. Maglione M, Costantinides F, Bazzocchi G. Classification of impacted mandibular third molars on cone-beam CT images. J Clin Exp Dent 2015:e224231.
14. Arora A, Patil B, Sodhi A. Validity of vertical tube shift method in determining the relationship between the mandibular third molar roots and the inferior alveolar nerve canal. J Korean Assoc Oral Maxillofac Surg 2015; 41(2):66-73.

15.Almendros-Marquez N, Berini-Aytes L, GayEscoda C. Evaluation of intraexaminer and interexaminer agreement on classifying lower third molars according tothe system of Pell and Gregory and Winter. J Oral Maxillofac Surg 2008; 66(5):893-9.

16. Tantanapornkul W, Okochi K, Bhakdinaronk A, Ohbayashi N, Kurabayashi T. Correlation of darkening of impacted mandibular third molar root on digital panoramic images with cone beam computed tomography findings. The British Institute of Radiology 2009. 38(1):11-6.

17.Szalma J, Lempel E, Jeges S, Olasz L. Darkening of third molar roots: panoramic radiographic associations with inferior alveolar nerve exposure. J Oral Maxillofac Surg. 2011 Jun;69(6):1544-9.

18. Nakamori K, Tomihara K, Noguchi M. Clinical significance of computed tomography assessment for third molar surgery. World Journal of Radiology 2014;6(7):417-423.

19.Soumalainen A, Venta I, Mattila M, Turtola L, Vehmas T, Peltola JS. Reliability of CBCT and other radiographic methods in preoperative evaluation of lower third molars. Oral Surg Oral Med Oral Pathol Oral Radiol Endod 2010; 109(2):276-284

20. Lee B, Park Y, Ahn J, Chun J, Park S, Kim M, et al. Assessment of the proximity between the mandibular third molar and inferior alveolar canal using preoperative 3D-CT to prevent inferior alveolar nerve damage. Maxillofacial Plastic and Reconsturctive Surgery 2015; $37(1): 30$.

21.Jhamb A, Dolas RS, Pandilwar PK. Comparative efficacyof spiral computed tomography and orthopantomography in preoperative detection of relation of inferior alveolar neurovascular bundle to impacted mandibular third molar. J Oral Maxillofac Surg 2009; 67(1):58-66

22. Nakayama K, Nonoyama M, Takaki $\mathrm{Y}$, Kagawa $T$, Yuasa K, Izumi K, et al. Assessment of the relationship between impacted mandibular third molars and inferior alveolar nerve with dental 3Dimentional computed tomography. J Oral Maxillofac Surg 2009; 67(12):2587-91.

23. Kim H-G, Lee J-H. Analysis and evaluation of relative positions of mandibular third molar and mandibular canal impacts. J Korean Assoc Oral Maxillofac Surg 2014:278-282. 
24.Ghaeminia H, Meijer GJ, Soehardi A, Borstlap WA, Mulder J, Berge SJ. Position of the impacted third molar in relation to the mandibular canal.Diagnostic accuracy of cone beam computed tomography compared with panoramic radiography. J Oral Maxillofac Surg 2009; 38(9):964-971.

25. Sammartino G, Wang H, Citarella R, Lepore M, Marenzi G. Analysis of occlusal stresses transmitted to the inferior alveolar nerve by multiple threaded implants. J Periodontol 2013;84(11):1655-61.

26.Park W, Choi J, Kim Y, Kim H, Lee S. Cortical integrity of the inferior alveolar canal as a predictor of parasthesia after third-molar extraction. J Am Dent Assoc 2010; $141(3): 271-8$.

Corresponding Author:

Gaye KESER

Marmara University Faculty of Dentistry

Department of Oral Diagnosis,

Maltepe, İstanbul, Turkey

Phone : +90 5326015166

E-mail : gaye.sezgin@marmara.edu.tr

E-mail : gayekeser@hotmail.com 